\title{
Fast and green synthesis of biologically important quinoxalines with high yields in water
}

\author{
Hossein Ghafuri*
}

Catalysts and Organic Synthesis Research Laboratory, Department of Chemistry, Iran University of Science and Technology, Tehran- P.O. Box 1684613114, Iran

\begin{tabular}{|c|c|}
\hline C H R O N I C L E & A B S T R A C T \\
\hline $\begin{array}{l}\text { Article history: } \\
\text { Received January 22, } 2014 \\
\text { Received in revised form } \\
\text { February 02, } 2014 \\
\text { Accepted 5 March } 2014 \\
\text { Available online } \\
7 \text { March 2014 } \\
\end{array}$ & $\begin{array}{l}\text { Optimal method were developed for the green synthesis of quinoxaline derivatives based on the } \\
\text { highly efficient and simple condensation reaction of various aromatic } 1,2 \text {-diketones and } 1,2- \\
\text { diamines in nearly quantitative yields in water. In this method we did not use any catalyst. The } \\
\text { very mild reaction conditions, the high yields of the products, and the absence of any catalyst } \\
\text { make this methodology an efficient and green route for synthesis of quinoxalines. }\end{array}$ \\
\hline $\begin{array}{l}\text { Keywords: } \\
\text { Biological activity } \\
\text { 1,2-Diketones } \\
\text { Diamines } \\
\text { Quinoxaline } \\
\text { Water }\end{array}$ & (C) 2014 Growing Science Ltd. All rights reserved. \\
\hline
\end{tabular}

\section{Introduction}

Development of strategically important processes which are environmentally cleaner and more efficient which lead to greater structural variation, with simple work up, high yields, purity, and minimizes the formation of waste, is currently receiving considerable attention ${ }^{1}$. In this context, water played an important role in these processes. Water is an elegant solution with the ultimate goal of hazard-free, waste-free and energy efficient for the synthesis of biologically active compounds with potential application in the pharmaceutical or agrochemical industries ${ }^{2-6}$. Quinoxaline derivatives are ubiquitous in many biologically important compounds ${ }^{7-10}$ such as antibiotics, which are known to inhibit the growth of Gram-positive bacteria and are also active against various transplantable tumors $^{11,12}$. They are used as dyes, ${ }^{13}$ antitumoralagents ${ }^{14}$ and catalyst's ligands. Therefore, the syntheses of biologically important quinoxaline derivatives have received considerable attention, and there are several reports for the synthesis of quinoxaline derivatives in the literature. Furthermore,

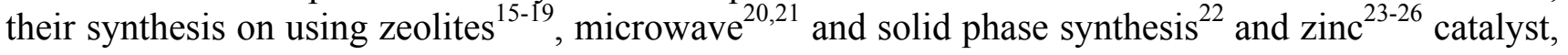


and $\mathrm{CAN}^{27}$ have also been reported. However, their reactions require toxic reagents, harmful organic solvents; catalyst limited substrate and moderate yields. Furthermore, to the best of our knowledge, no report about condensation reaction of diamines and diketone without any catalyst has been reported in the literature.

Our interest in green chemistry led us to contemplate the possibility of using water as highly potential solvent for quinoxaline synthesis. Obviously, our goal was to develop highly efficient, green and preparative simple procedure for industrial large-scale production of quinoxaline with simple condensation of aromatic 1,2-diketones and 1,2-diamines with high purity and in excellent yield without catalyst in pure water (Scheme 1).

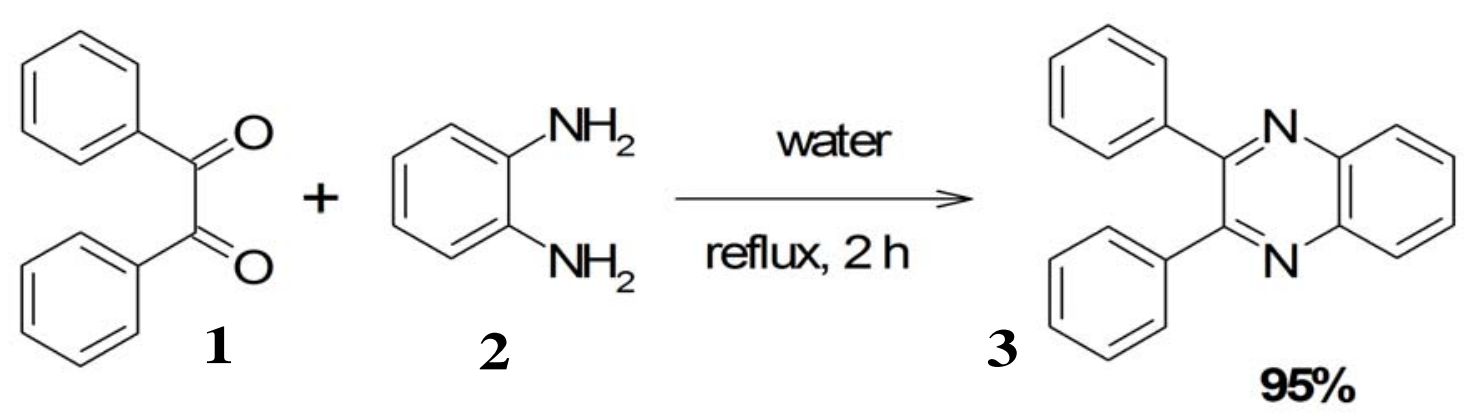

Scheme 1 Synthesis of quinoxaline derivatives in water

\section{Results and Discussion}

In an initial experiment, aromatic 1,2-diketone 1 ( $3 \mathrm{mmol})$ was treated with o-phenylenediamine 2 $(3 \mathrm{mmol})$ in water $(20 \mathrm{~mL})$ in the absence of any catalyst at reflux conditions. After $2 \mathrm{~h}$, starting materials were consumed and the corresponding quinoxaline 3 was formed as the only detectable product and isolated in 95\% yield (Scheme1). To test the feasibility of a large-scale reaction, 1 (10 mmol) was treated with $2(10 \mathrm{mmol})$ in water $(50 \mathrm{~mL})$ at reflux condition. The product was isolated in $90 \%$ yield after $2 \mathrm{~h}$. Furthermore, it was possible to monitor the reaction visually. A white suspension were obtained after addition of the o-phenylenediamine and aromatic 1,2-diketone to the water, and the reaction mixture became orange viscose liquid or solids after the reaction is complete.

Furthermore, it is important to note that, in the large-scale production, the final treatment is very simple without using any organic solvent and the pure product was obtained by simple decantation. Next, the scope and limitation of this simple process were explored by using a wide range of aromatic 1,2-diketones and 1,2-diamines. A variety of structurally diverse aromatic diamines and diketones underwent the simple condensation reaction smoothly without using any catalyst for affording the quinoxaline derivatives to high yields. The results are summarized in Table1. We show proposed mechanism in Scheme 2. With symmetrical aromatic diamines the reaction showed good product yields. With electron donating substituents in the amine part, increased yields of products were obtained and the effect is the reverse with electron with drawing substituents. On the other hand, electron donating substituents associated with aromatic 1,2-diketone decreased the product yields and with electron with drawing groups the effect is opposite. However, the variations in the yields were very small and both substituted aromatic diamines such as 4-chloro and 3-methyl gave the condensed products in excellent yields in water. 
Table 1 synthesis of quinoxalinederivativesin water.

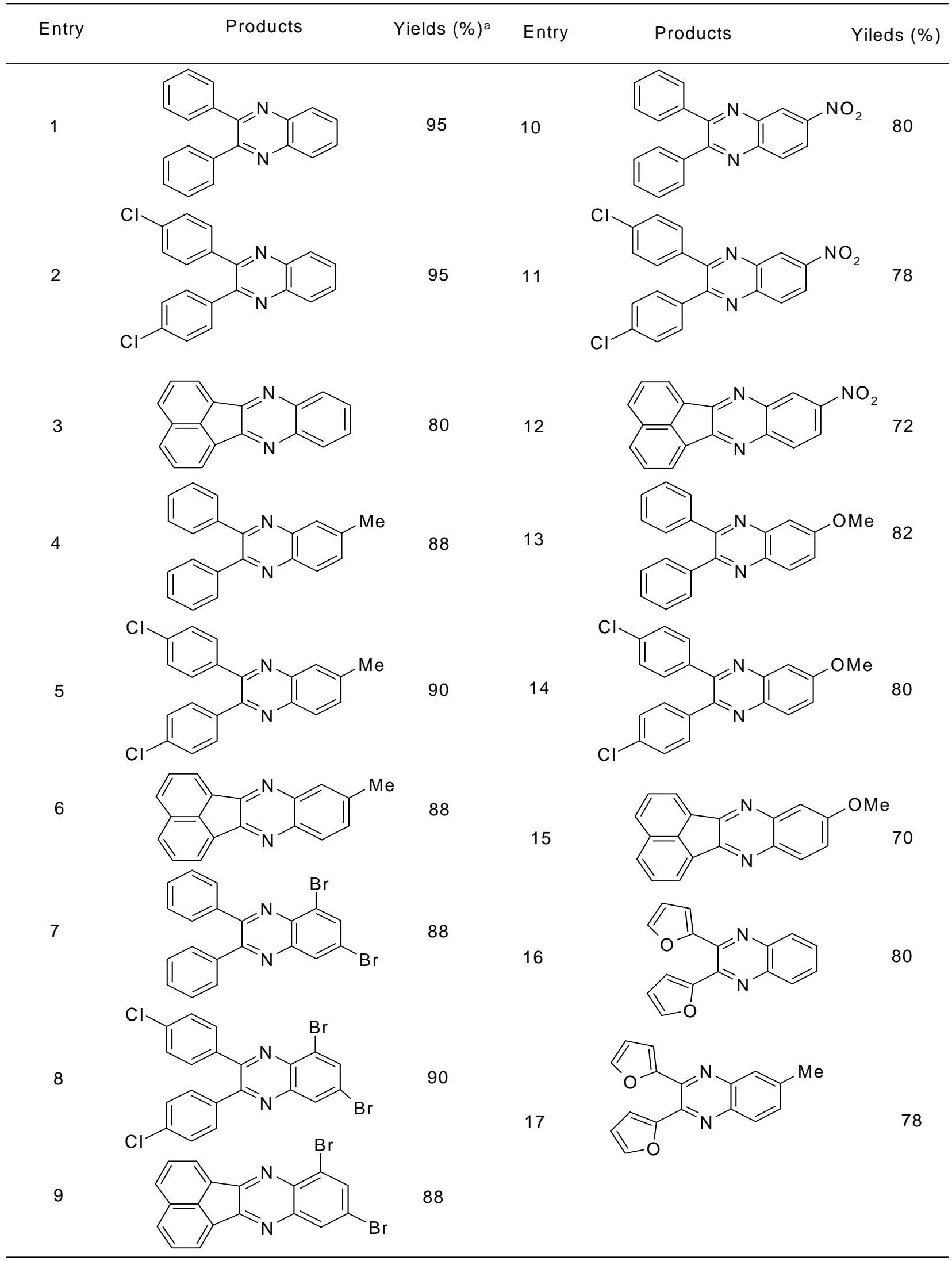

a Isolated yields 


\section{Conclusions}

As a result of the investigation, we have demonstrated a highly efficient and entirely green protocol for simple condensation of aromatic 1,2-diketonesand 1,2-diamines which leads to production of biologically important quinoxaline derivatives. In comparison with recently reported methods, the reactions proceed smoothly under mild conditions to furnish the respective products in short reactiontimes and high yields.

\section{Acknowledgements}

We are grateful to the Department of Chemistry of Iran University of Science and Technology for financial support.

\section{Experimental}

\subsection{Materials and Methods}

All chemicals were of research grade and were used as obtained from Aldrich or Merck. The reactions were carried out in a round-bottomed flask of $10 \mathrm{ml}$ capacity or test tube. ${ }^{1} \mathrm{H}$ and ${ }^{13} \mathrm{C} \mathrm{NMR}$ spectra were recorded with a Bruker EX 500 FT NMR. All NMR data were obtained in $\mathrm{CDCl}_{3}$ and DMSO- $d_{6}$ solution and chemical shifts were given in ppm relative to TMS and are compared with the reported literature values. Melting points were determined on a Buchi 541 apparatus and are uncorrected.

\subsection{General procedure for Synthesis of quinoxaline in water}

A mixture of $o$-phenylenediamine $(3 \mathrm{mmol})$ and 1,2-dicarbonyl $(3 \mathrm{mmol})$, water $(10 \mathrm{~mL})$ were added and stirred at reflux conditions for the 60- $200 \mathrm{~min}$. After the reaction was completed, pure products were isolated by filtration and washing with hot water, or ethanol. Aqueous mixture was extracted with $10 \mathrm{ml}$ of diethylether or ethyl acetate and dried over anhydrous $\mathrm{Na}_{2} \mathrm{SO}_{4}$, and solvent was removed under reduce pressure to give the desired products. The crude product was analyzed by ${ }^{1} \mathrm{H}$ and ${ }^{13} \mathrm{C}$ NMR. Further purification was carried out by crystallization.

\subsection{Spectral Data of Selected Compounds}

\subsubsection{2,3-Diphenylquinoxaline (Table 1, Entry 1)}

White solid, mp 126- $127^{\circ} \mathrm{C} ;{ }^{1} \mathrm{HNMR}\left(\mathrm{CDC1}_{3}, 500 \mathrm{MHz}\right) \delta \mathrm{ppm}: 8.21$ (dd, J=3.40,6.32 Hz, $\left.2 \mathrm{H}\right)$, $7.80(\mathrm{dd}, J=3.40,6.32 \mathrm{~Hz}, 2 \mathrm{H}), 7.58(\mathrm{~m}, 4 \mathrm{H}), 7.40(\mathrm{~m}, 6 \mathrm{H}) ;{ }^{13} \mathrm{C}$ NMR $\left(\mathrm{CDCl}_{3}, 125 \mathrm{MHz}\right) \delta \mathrm{ppm}$ : $152.0,143.6,142.6,141.9,137.1,130.6,130.5,130.0,129.8,129.5,129.2,127.9$; IR (KBr) $v \max \left(\mathrm{cm}^{-}\right.$ $\left.{ }^{1}\right): 3050,1538,1340,760,722$.

\subsubsection{2,3-Bis(4-chloro-phenyl)quinoxaline (Table 1, Entry 2)}

Mp 150-151 ${ }^{\circ} \mathrm{C} ;{ }^{1} \mathrm{HNMR}\left(\mathrm{CDCl}_{3}, 500 \mathrm{MHz}\right) \delta$ ppm: $8.08(\mathrm{dd}, J=3.40,7.21 \mathrm{~Hz}, 2 \mathrm{H}), 8.00(\mathrm{dd}$, $J=3.40,6.40 \mathrm{~Hz}, 2 \mathrm{H}), 7.94(\mathrm{dd}, J=5.42,8.64 \mathrm{~Hz}, 4 \mathrm{H}), 7.30-7.52(\mathrm{~m}, 4 \mathrm{H}) ;{ }^{13} \mathrm{C} \mathrm{NMR}\left(\mathrm{CDCl}_{3}, 125\right.$ $\mathrm{MHz}) \delta$ ppm:152.7, 141.7, 140.6, 139.5132 .3 130.3, 129.5, 129.0, 128.8, 128.1; IR (KBr) vmax $\left(\mathrm{cm}^{-}\right.$ $\left.{ }^{1}\right): 3060,1540,1550,1341,1210,845,730$. 


\subsubsection{6-Methyl-2,3-diphenylquinoxaline (Table 1, Entry 4)}

White solid: $\mathrm{mp} 117-119^{\circ} \mathrm{C} ;{ }^{1} \mathrm{H}$ NMR (DMSO/d, $\left.500 \mathrm{MHz}\right) \delta \mathrm{ppm:} 8.12(\mathrm{~d}, J=8.50 \mathrm{~Hz}, 1 \mathrm{H})$, $7.92(\mathrm{~s}, 1 \mathrm{H}), 7.60(\mathrm{dd}, J=1.70,8.50 \mathrm{~Hz}, 1 \mathrm{H}), 7.52(\mathrm{~m}, 4 \mathrm{H}), 7.32(\mathrm{~m}, 6 \mathrm{H}), 2.62(\mathrm{~s}, 3 \mathrm{H}) ;{ }^{13} \mathrm{C}$ NMR $\left(\mathrm{DMSO} / \mathrm{d}_{6}, 125 \mathrm{MHz}\right) \delta$ ppm: 153.7, 153.0, 141.7, 140.8, 140.1, 139.7, 132.7, 130.3, 129.1, 129.0128.6, 128.4, 22.3; IR (KBr) vmax $\left(\mathrm{cm}^{-1}\right)$ : 3060, 1662, 1590, 1212, 870, 711, 642.

\subsubsection{6-Methyl-2,3- Bis(4-chloro-phenyl) quinoxaline (Table 1, Entry 5)}

White solid: ${ }^{1} \mathrm{H}$ NMR (DMSO/d $\left.6,500 \mathrm{MHz}\right) \delta \mathrm{ppm}: 8.11(\mathrm{~d}, J=8.30 \mathrm{~Hz}, 1 \mathrm{H}), 7.90(\mathrm{~s}, 2 \mathrm{H}), 7.61$ $(\mathrm{dd}, J=1.72,8.52 \mathrm{~Hz}, 1 \mathrm{H}), 7.50-7.60(\mathrm{~m}, 3 \mathrm{H}), 7.30-7.34(\mathrm{~m}, 6), 2.62(\mathrm{~s}, 3 \mathrm{H}) ;{ }^{13} \mathrm{C} \mathrm{NMR}\left(\mathrm{DMSO} / \mathrm{d}_{6}\right.$, $125 \mathrm{MHz}) \delta$ ppm: 153.4, 153.0, 141.8 140.6, 140.2, 139.6, 132.7, 130.1, 129.2, 129.0, 128.7, 128.5, 22.7; IR (KBr) vmax $\left(\mathrm{cm}^{-1}\right): 3062,1664,1592,1213,872,712,641$.

\subsubsection{6-Nitro-2,3-diphenylquinoxaline (Table 1, Entry 10)}

Mp192-193 ${ }^{\circ} \mathrm{C} ;{ }^{1} \mathrm{H}$ NMR $\left(\mathrm{CDCl}_{3}, 125 \mathrm{MHz}\right) \delta \mathrm{ppm}: 9.12$ (d, $\left.J=2.32 \mathrm{~Hz}, 1 \mathrm{H}\right), 8.50$ (dd, $J=2.32$, $9.11 \mathrm{~Hz}, 1 \mathrm{H},), 8.38(\mathrm{~d}, J=9.11 \mathrm{~Hz}, 1 \mathrm{H}), 7.58(\mathrm{~m}, 4 \mathrm{H}), 7.42$; (m, 6H); IR (KBr) vmax (cm-1): 3052, 2933, 1625, 1338, 1139.

\section{References}

1. Adams D. J., Dyson P. J., and Tavener S. J. (2005) Chemistry in alternative reaction media, Ed, John Wiley \& Sons.

2. Leadbeater N. E. (2005) Fast, easy, clean chemistry by using water as a solvent and microwave heating: The suzuki coupling as an illustration. Chem. Commun., (23), 2881-2902.

3. Manabe K., Iimura S., Sun X.M., and Kobayashi S. (2002) Dehydration reactions in water. Brønsted acid-surfactant-combined catalyst for ester, ether, thioether, and dithioacetal formation in water. J. Am. Chem. Soc., 124(40), 11971-11978.

4. Chankeshwara S. V., and Chakraborti A. K. (2006) Catalyst-free chemoselective n-tertbutyloxycarbonylation of amines in water. Org. Lett., 8(15), 3259-3262.

5. Ranu B. C., and Banerjee S. (2007) Significant rate acceleration of the aza-michael reaction in water. Tetrahedron Lett., 48(1), 141-143.

6. Saito A., Takayama M., Yamazaki A., Numaguchi J., and Hanzawa Y. (2007) Synthesis of tetrahydroisoquinolines and isochromans via pictet-spengler reactions catalyzed by brønsted acid-surfactant-combined catalyst in aqueous media. Tetrahedron., 63(19), 4039-4047.

7. Sarges R., Howard H. R., Browne R. G., Lebel L. A., Seymour P. A., and Koe B. K. (1990) 4amino [1, 2, 4] triazolo [4, 3-a] quinoxalines. A novel class of potent adenosine receptor antagonists and potential rapid-onset antidepressants. J. Med. Chem., 33(8), 2240-2254.

8. Gomtsyan A., Bayburt E. K., Schmidt R. G., Zheng G. Z., Perner R. J., Didomenico S., Koenig J. R., Turner S., Jinkerson T., and Drizin I. (2005) Novel transient receptor potential vanilloid 1 receptor antagonists for the treatment of pain: Structure-activity relationships for ureas with quinoline, isoquinoline, quinazoline, phthalazine, quinoxaline, and cinnoline moieties. J. Med. Chem.,48(3), 744-752.

9. Seitz L. E., Suling W. J., and Reynolds R. C. (2002) Synthesis and antimycobacterial activity of pyrazine and quinoxaline derivatives. J. Med. Chem., 45(25), 5604-5606.

10. Jaso A., Zarranz B., Aldana I., and Monge A. (2005) Synthesis of new quinoxaline-2-carboxylate 1, 4-dioxide derivatives as anti-mycobacterium $t$ uberculosis agents. J. Med. Chem.,48(6), 20192025.

11. Dell A., Williams D. H., Morris H. R., Smith G. A., Feeney J., and Roberts G. C. (1975) Structure revision of the antibiotic echinomycin. J. Am. Chem. Soc., 97(9), 2497-2502.

12. Sato K., Shiratori O., and Katagiri K. (1967) The mode of action of quinoxaline antibiotics. Interaction of quinomycin a with deoxyribonucleic acid. J. Antibi., 20(5), 270. 
13. Renault j., Baron M., Mailliet $\mathrm{p}$ and et al. (1981) Heterocyclic quinones.2.Quinoxaline-5,6-(and 5-8)-diones-Potential antitumoral agents. Eur. J. Med. Chem.,16 (6), 545-550.

14. Xianghong Wu., Anne E. V. Gorden (2007) Regioselective Synthesis of Asymmetrically Substituted 2-Quinoxalinol Salen Ligands. J. Org. Chem., 72 (23), 8691-8699.

15. Antoniotti S., and Duñach E. (2002) Direct and catalytic synthesis of quinoxaline derivatives from epoxides and ene-1, 2-diamines. Tetrahedron Lett., 43(22), 3971-3973.

16. Raw S. A., Wilfred C. D., and Taylor R. J. (2003) Preparation of quinoxalines, dihydropyrazines, pyrazines and piperazines using tandem oxidation processes. Chem. Commun.,(18)., 2286-2287.

17. Goswami S., and Adak A. K. (2005) A novel one-pot two-component synthesis of tricyclic pyrano quinoxalines. Tetrahedron Lett.,46(2), 221-224.

18. Xekoukoulotakis N., Hadjiantoniou-Maroulis C., and Maroulis A. (2000) Synthesis of quinoxalines by cyclization of $\alpha$-arylimino oximes of $\alpha$-dicarbonyl compounds. Tetrahedron Lett., 41(52).10299-10302.

19. Goswami S., and Adak A. K. (2002) The first microwave-assisted regiospecific synthesis of 6substituted pterins. Tetrahedron Lett., 43(46), 8371-8373.

20. Zhao Z., Wisnoski D. D., Wolkenberg S. E., Leister W. H., Wang Y., and Lindsley C. W. (2004) General microwave-assisted protocols for the expedient synthesis of quinoxalines and heterocyclic pyrazines. Tetrahedron Lett.,45(25), 4873-4876.

21. Wu Z., and Ede N. J. (2001) Solid-phase synthesis of quinoxalines on synphase ${ }^{\mathrm{TM}}$ lanterns. Tetrahedron Lett., 42(45), 8115-8118.

22. Heravi M. M., Tehrani M. H., Bakhtiari K., and Oskooie H. A. (2007) Zn [(1) proline]: A powerful catalyst for the very fast synthesis of quinoxaline derivatives at room temperature. Catal. Commun., 8(9), 1341-1344.

23. Heravi M. M., Bakhtiari K., Bamoharram F. F., and Tehrani M. H. (2007) Wells-dawson type heteropolyacid catalyzed synthesis of quinoxaline derivatives at room temperature. Monatsh. Chem., 138(5), 465-467.

24. Hazarika P., Gogoi P., and Konwar D. (2007) Efficient and green method for the synthesis of 1, 5-benzodiazepine and quinoxaline derivatives in water. Synth. Commun.,37(19), 3447-3454.

25. Heravi M. M., Bakhtiari K., Oskooie H. A., and Taheri S. (2008) Mncl $_{2}$-promoted synthesis of quinoxaline derivatives at room temperature. Heteroatom Chem., 19(2), 218-220.

26. More S. V., Sastry M., and Yao C.-F. (2006) Cerium (iv) ammonium nitrate (can) as a catalyst in tap water: A simple, proficient and green approach for the synthesis of quinoxalines. Green Chem., 8(1), 91-95.

27. Zhou J. F., Gong G. X., Shi K. B andZhi S. J (2009) Montmorillonite K-10: an efficient and reusable catalyst for the synthesis of quinoxaline derivatives in water. Chin. Chem. Lett., 20, 672.

28. Zhou J. F., Gong G. X., Zhi S.J. ., Duan X.L (2009) Microwave- assisted catalyst-free and solventfree method for the synthesis of quinoazlines. Synth. Commun., 39, 3743. 